\title{
THE USE OF INFORMAL ASSESSMENT IN EVALUATING STUDENTS' SPEAKING ABILITY: STUDENTS' AND TEACHERS' VOICES
}

\author{
Arifin Nur Himawan \\ arifinhimawan92@gmail.com \\ Department of English Education, Universitas Ahmad Dahlan, Yogyakarta - Indonesia \\ Dinar Purwati \\ dynar.anisa13@gmail.com \\ Department of English Education, Universitas Ahmad Dahlan, Yogyakarta - Indonesia
}

\begin{abstract}
In this era, English becomes an important subject to be learned in senior high school. In the case of English Language Learning, the curriculum 2013 requires the students to have critical thinking and active learning that should be mastered in both written and spoken. Unfortunately, there are major problems faced by the students such as less confidence and low motivation in speaking. Thus, this research was conducted under a phenomenological study that involved two EFL teachers and ten EFL students in a senior high school. The Semi-structured interview had been conducted to obtain some information related to the students' and teachers' perceptions toward the use of informal assessment in evaluating speaking. The result presents that the use of informal assessment is useful to improve the students' interest to perform speaking. Furthermore, it enhances the students' confidence and motivation to perform the speaking test. Hence this research has some implications for other researches to develop a further discussion about the use of informal assessment in other language skills.
\end{abstract}

Keywords: Informal Assessment, Student's Confidence, Student's Motivation

\section{Sari}

Bahasa inggris menjadi salah satu mata pelajaran yang sangat penting untuk dipelajari di SMA. Dalam penerapan kurikulum 2013 pembelajaran bahasa inggris diharapkan mampu untuk mendorong siswa memiliki keterampilan berfikir kritis dan memiliki skill bahasa aktif baik secara lisan maupun tertulis. Sayangnya, hal ini belum dapat di wujudkan lantaran kurangnya rasa percaya diri dan motovasi belajar khususnya dalam keterampilan berbicara. Penelitian ini di kembangkan dengan menggunakan metode penelitian fenomenologi yang melibatkan dua orang guru bahasa inggris dan sepuluh orang siswa tingkat SMA sebagai responden dari penelitian ini. Teknik pengambilan 
data dilakukan dengan cara wawancara semistruktur, hal ini bertujuan untuk memperoleh data dan informasi terkait dengan persepsi siswa dan guru terhadap penggunaan penilaian informal dalam skill berbicara. Hasil penelitian menunjukkan bahwa penggunaan penilaian informal sangat berguna untuk meningkatkan minat siswa dalam mengikuti pembelajaran speaking, selain itu penggunaan penilaian informal dapat meningkatkan motivasi dan rasa percaya diri siswa dalam mengikuti tes speaking. Oleh karenanya, penelitian ini perlu dikembangan lebih lanjut oleh para peneliti untuk dapat diaplikasi di berbagai aspek skill bahasa tidak hanya dalam skill berbicara.

kata kunci: Penilaian informal, Kepercayaan diri siswa, Motivasi siswa

Received 2020-08-12 accepted 2020-09-30 published 2020-09-30

APA Citation: Himawan, A.N., Purwati, D. (2020). THE USE OF INFORMAL ASSESSMENT IN EVALUATING STUDENTS' SPEAKING ABILITY: STUDENTS' AND TEACHERS' VOICES. Research and Innovation in Language Learning 3(3). pp. 208219 http://dx.doi.org/10.33603/rill.v3i3.3986

\section{Introduction}

The current demand for global changes is the use of international language as global communication. This condition creates some challenges for students to have adequate communication skills in global communication. As mentioned by Rahmawati \& Ertin (2014) the development of English as the global language is strengthened and as a consequence. It brings shed light toward the status of English language, the nature of English, and the fact that English is widely used in multilingual context. It is very beneficial to be used to maintain the communication among non-native speaker as well as native-speaker (Vodopija-Krstanović \& Marinac, 2019). Regarding to this case, the teachers need to prepare students to master English in all skills of language, especially in speaking skills. It is not easy for preparing students to face this condition. There are some challenges in speaking class especially when the teacher wants to conduct an assessment for speaking skills. As mentioned by Bachman (1990), the current problem in language assessment is to specify language abilities. While in Thornbury (2005), he explains that in assessing speaking there should be a great consideration to balancing between accuracy and fluency. Besides, Bachman (1990) explains that the important thing to be considered by the tester is about how to define the test which has authenticity because the current framework of language use is the concept of language as communication, and recognize the importance of the context, both discourse, and sociolinguistics where the language is used. 
As an English teacher, we should have a good understanding of how to teach and how to assess the students' speaking ability. The teacher must be aware of the task that has developed to the test taker and we need to think about the wash back of the assessment (Brown and Abeywickrama, 2010). According to Ounis (2017), the central focus of current EFL assessment concerns to go beyond the traditional standardized forms. It reforms to be communicative oriented assessment. A good assessment instrument should cover the nature of speaking. Luoma (2013) described that a speaking is a special thing to be considered because of its interactive nature. It means that speaking often to be tested in live interaction where the discourse is not entirely predictable. Besides, Pawlak (2015) also states that speaking is interactive. It is an important language skill that relates to expressing ideas, opinions, or feelings to others.

Another aspect that should be considered by the teacher in developing a good speaking assessment is the complexities of the assessment. Ferdiant (2016) explains that speaking assessment should be clear in complexities to define the aspect and the language features based on real world criteria. The complexities that frequently happen in the speaking class is about the balance of fluency and accuracy (Bailey \& Nunan, 2004). Teacher can't ignore those aspects because it is very beneficial for the students to have good speaking skills in any various contexts. Bygate (1987) states that the language teacher needs to train our students to learn about the knowledge and skill of speaking in various context. It helps the students to use their language skill based on daily communication. While Goh \& Burns (2012) explain that one of the ways that influence the students speaking ability is the environment. The environment can be one of the factors that have a good contribution to the student`s language learning. The challenges happen in English Language Teaching is the anxiety of the students to practice speaking in the classroom. Goh \& Burns (2012) explain that some factors can create a student's anxiety in using the target language. These factors are related to the personal and interpersonal condition, learner belief about language learning, instructor belief about language learning, instructor-learner interaction, classroom procedures, and language testing applied. There are three main reasons for getting students to speak in the classroom: chances to practice real-life speaking in the safety of the classroom, trying to 
use any or all of the language they know, and having opportunities to activate the various elements of language (Harmer, 2007). Moreover, the student's motivation is an essential aspect to be considered for having successful learning, it energizes and directs the student's behavior (Badroeni, 2018).

There are some principles that should be considered by the teacher to develop a good assessment. Luoma (2013) explains that the realistic simulation of the task can help our students to perform their language well on its function. The teacher should begin the task design with the need for assessment situations and it should cover the practical circumstances which can be arranged in some general guidelines. Madani, (2019) promotes that generating the scales is very beneficial to provide incredible criteria to measure the intended ability. Therefore, the use of rating scales is preferable to maintain a greater validity and reliability. In addition Hughes (2002) explains that testing speaking ability should cover the following aspects: accent, grammar, vocabulary, fluency, and comprehension. These ratings then weighted and totaled.

The use of suitable assessment type is also an essential aspect to be considered. Cammeron (2001) explains that assessment is more than testing, it means that the teacher should consider that the assessment must have a good wash back to present the language skill in various context. In previous times, the teacher uses a Formal Assessment in assessing a student's speaking ability. It is the conventional assessment where the students are given a specific scoring and grading formats, using a certain frame time and condition. Ayuanita (2013) explains that formal assessment is designed in deliberately using the conventional feedback, conducted in a certain time frame, prepared for (and some feared) by the students, and characterized by offering specific scoring or grading formats. The use of formal assessment is merely used to make a judgment for the students' ability and to generate the students' improvement to reach the highest standard (Widiastuti \& Saukah, 2017). In the current condition, the use of formal assessment needs to be improved, therefore the teacher must develop the assessment in a more stylish design. 
Many kinds of research are developed to investigate the suitable teaching strategy and assessment to improve students' speaking ability. Wulandari (2014) and Nirmawati (2013), explain that the use of interesting material and the authentic task can help students to improve their speaking ability and also their motivation in engaging the learning process. While Himawan (2015) and Armasita (2017) explain that the use of interesting and various styles of learning activities can improve the students' speaking skills. By implementing an interactive learning strategy may improve the learning quality of students. Those researches are well designed although there is still a lack of use of the assessment task. The assessment tasks used in those researches are still using standardized and formal test where the students should perform the dialogue-based determined topic then the teacher assesses their performance based on the criteria and weighting strategy that have been designed by the teacher. Those kinds of tasks should be modified to improve the washback of language assessment and its function in a reallife situation.

The current educational trends promote the use of Informal assessment as an alternatives way to assess the students' language skills. It is very beneficial to assess not only the language competencies but also the language function in a contextual manner. Hillyard (2013) that informal assessment is conducted by monitoring and recording the students' progress which means that it is focused on the students' progress rather than the product. It allows the students not to have feared situation because the assessment is conducted in classroom daily activity, and it is necessary to develop assessment method which allows the students to demonstrate their understanding and learning by doing, showing and telling. Moreover, the implementation of Individual or group projects, presentations, and other speaking performances is beneficial to support the informal assessment (Dagmar, 2012). Hence, this research is conducted to investigate the potential of informal assessment in assessing students' speaking ability. The researchers develop some questions to investigate this case. 1) How does the informal assessment improve the students' learning interest? 2) How does the informal assessment increase the students' confidence in joining the speaking assessment? 3) How does the informal assessment enhance the students' motivation to join the speaking assessment? 


\section{Methods}

The qualitative approach had been implemented to describe the influence of informal speaking in assessing speaking skills based on students' and teachers' perspectives. This research was designed under phenomenological study that analyzed the phenomenon happened in EFL senior high school students where they got an anxiety to join the speaking test because of the feeling of the nervous and under-pressure situation. Groenewald (2004) explains that the purpose of phenomenological research is to describe a certain phenomenon accurately based on the truth of the fact. By applying this method, the researcher will have a chance to find out the data to describe the related phenomenon toward students' motivation and confidence in speaking assessment.

Further, this study used purposive sampling in determining the participant. As explained by Etikan (2016), purposive sampling enables us to have a chance to determine the participants based on their quality possessed. Some criteria had been set up to be used as the measurement for the participants. For the teacher, the criteria which have been set is the teacher who has at least five years of teaching experience, and the teacher must be the English teacher. While for the students, the criteria which have been set required the students to have some experiences in joining the formal speaking assessment, and they experienced some problem in joining the formal assessment. As a result, there are two teachers and ten students available to meet the criteria of being the participant.

To collect the data, the researcher conducted some investigations related the phenomena. After that he conducted some interview with the students get the data of the phenomenon based on students' perspectives. As explained by Christensen et al. (2014), the technique for data collection in phenomenological research can be gained by using an in-depth interview or open-ended questionnaires. Thus, this study used the semistructured interview to get detailed information from the participants about the phenomenon based on students' experiences and perspectives. The next step is developing the descriptive comments taken from the interview transcript by identifying the key phrase, explanations, description, and emotional despond from the participants. And finally the researcher focus on describing how the transcript reflects the phenomenon being studied (Cooper, Fleischer, \& Cotton, 2012). 


\section{Results and Discussion}

In this section, the researcher provides some findings to answer the question stated in the research objectives. The finding concerns the use of informal assessment in improving the students' interest, confidence, and motivation to join a speaking test. The findings are being described and analyzed based on the teachers' and students' perspectives toward the implementation of informal assessment in assessing students' speaking ability. The research finding is being discussed in the following explanation.

\section{The informal assessment improves students' interest in the speaking test.}

In the current curriculum design, especially in curriculum 2013, the students are expected to have critical thinking toward certain phenomena and problems. This situation requires the teacher to have some adequate skills to teach students by using appropriate learning methods, approaches, and techniques. The use of an appropriate assessment method is required to measure the students' ability and to help them to achieving the learning goals. Unfortunately, there are some difficulties faced by the students in achieve the learning goals. This might happen because of a complicated assessment that should be accomplished by the students. One of the factors that influence the students to feel anxiety is the language testing itself (Goh \& Burns, 2012). After conducting the interview, the researcher found that students have less confidence and low motivation in joining the speaking assessment. In addition, they feel nervous and under pressure when they are joining the formal assessment.

\footnotetext{
"There are some obstacles faced by the students such as less confidence and low motivation in performing speaking in English, they are afraid for making mistakes in grammar, and they are being shy to their partner if they make a mistake such as faltered utterance." (Teacher 1)

"One factor that makes me become nervous and feel under pressure to perform speaking in front of the classroom is because of mispronouncing and make some mistake then I felt so nervous in front of the class". (Student 1)
}

By considering some factors above, we need to have some innovation in conducting the assessment process. We need to changes the formal assessment to another assessment method that can encourage students to be more interested in joining the assessment. Fortunately, the use of informal assessment is useful to gain the students' interest in 
joining the speaking assessment. From the teacher's perspective, it is necessary to develop an informal speaking assessment that can be used in improving students' interest and motivation to join the speaking assessment.

"On my side, certainly it can be used to help our students in solving the problem because it can make the students become interested to learn about speaking. Because last time I have provided some assessments for the students but we don't use any YouTube channel because at that time youtube was not available yet. I tried to make some assessments for the students to make a short video about an advertisement, then they took the video outside and it was very interesting when we can relate to real life. It can encourage the students to be very enthusiastic to join this kind of assessment. So informal assessment is very useful to improve the students' enthusiasm." (Teacher 2)

While from the students' perspective, it revealed that the use of informal assessment is an interesting way to enhance their confidence in joining the speaking assessment. They prefer to engage in a supportive learning environment where they can maximize their talent and creativity in performing speaking.

\footnotetext{
"In my side, it is very interesting because there are some teachers that give us the assignment to create the short video then upload it on YouTube and I am really enjoyed it. I prefer to join some activities outdoor like you said as the informal assessment method because we have much time to prepare, and maximize our creativity so I prefer to join informal speaking." (Student 2)
}

From the explanation above we can see that the use of informal assessment can help the students to have a good interest in joining the speaking assessment. By implementing the informal assessment, it reduces the students' feeling of anxiety to join the assessment. This finding is relevant to the statements of Badroeni (2018) who explained that there are some factors that make students be able to speak in the classroom like the chance of practicing real life speaking.

\section{The informal assessment increases students' confidence.}

There are so many challenges faced by the language teacher to determine the suitable technique to design speaking assessment. The research finding showed that informal assessment can be used as an alternative way to improve students' confidence in joining speaking assessment. Based on the teacher's perspective, the implementation of informal assessment is useful to improve the students' confidence in joining the speaking assessment. 
"In my opinion, there is some informal assessment task that can be developed to improve the student's confidence say for example we can give some assignment for the students but it is not done in the classroom, means that we can conduct some outdoor activities such as making flog videos or out-door project." (Teacher 2)

We need to have some innovation and improvement in assessing speaking because speaking is one of the important language skill which should be mastered by students. As we know that in this current age, our students have some social media such as Instagram and YouTube account, therefore for the future it will be better for us develop some informal assessment task by giving instruction to the students to make some videos then they should upload the video in their youTube account, and we can make some assessment through their video. This kind of assessment can build the students' confidence in joining the speaking test, but we must ensure that the content of the video should be validated and trustworthy to avoid some bullying comments from the Netizen. (Teacher 1)

While from the students' perspective, the use of informal assessment enhances their confidence in joining speaking assessment. Several students prefer to follow outdoor activities because they feel more comfortable in a positive environment. They feel confident when they use informal assessment rather than a formal assessment.

\footnotetext{
"In my opinion, it will be a very interesting way for the students because it can enable the students to have a new experience and it can improve the student's confidence." (Student 3)

"I agree if we make some flog video, it will be more interesting, and it can improve my confidence because we only face the camera not directly to the real audience." (Student 4)
}

From the explanation above we can see that the use of informal assessment builds more stylish environment for students. By using those kinds of task, it encourages the students to have good confidence in demonstrating speaking. As mention in Brown (2000), learners' belief of accomplishing the task in at least partially can be the factor of their success in attaining the task. Speaking assessment is not only conducted to elicit the students' language competence but also allows students to demonstrate their understanding and learning by doing, showing, and telling (Hillyard, 2013).

\section{The informal assessment enhances students' motivation.}

Motivation is an important aspect to be developed in the learning process. It can be raised through the dynamic language classroom. As mention by Tampubolon (2018), students' motivation can be raised when the language classroom becomes fun and 
dynamic place to be. From the data interview, it was found that the informal assessment brings some benefits for students toward their motivation. This can be conducted in various techniques which is more relaxing and flexible in time. Therefore, the students can be more comfortable and confident to accomplish the assessment given by the teacher.

"In my perspective, this kind of assessment technique certainly can be used to improve the students' motivation and confidence because by creating some video, flog and another stylish activity the students become more enthusiast because the previous time I try to make a project to make a video about advertising product then I develop the assessment task through this project, but at this time we don't use YouTube channel so maybe the next time we need to try this on students." (Teacher 2)

While From the student's perspective, it can be found that the informal assessment brings some benefits for them because it can be conducted in various techniques which is more relax, and flexible of time therefore the students can be more comfortable and confidence to accomplish the assessment given by the teacher. It brings a high motivation for the students to enroll the speaking assessment.

\footnotetext{
"In my point of view, this kind of assessment technique can help us to improve our motivation and confidence to perform speaking. The use of informal assessment can be another alternative assessment that provides an interesting task without any pressure situation. It has a flexible time frame so I think it is a good way to be implemented." (Student 5)
}

After having a deep understanding of the data finding and discussion above, we can see that the use of informal assessment brings a positive impact on students' motivation to join the speaking assessment. Improving the students' motivation is very important to ensure the students reach the learning goal.

\section{Conclusion \& recommendation}

From the discussion above, we can see that the major problem and difficulties faced by the students to perform the formal speaking test are less confidence in joining the formal speaking test and low motivation toward the assessment task provided by the teacher. Furthermore, most students feel nervous and under pressure when performing speaking in front of the class. Even they are not interested in the formal assessment task provided by the teacher, it is necessary for the language teacher to develop the informal speaking test as an alternative way of assessing speaking. The use of informal speaking 
has some positive feedback from the students and also the teachers. Based on the teachers' and students' perspectives, informal speaking can provide an interesting way of assessing speaking. It can enhance the student's confidence and motivation to perform and join the speaking test. The researcher recommends to the next following researcher to have some contribution to conduct any further research about the informal assessment.

\section{References}

Armasita. (2017). Improving Students 'Speaking Skill in English Lesson With Action Learning Strategy At Eight Grade of MTS PAB 1 Helvetia. The State Islamic University of North Sumatera.

Ayuanita, K. (2013). Assessing listening in the language classroom. Okara, 1(8).

Bachman, L. F. (1990). Fundamental Considerations in Language Testing. Oxford University Press.

Badroeni, B. (2018). Improving Students' Motivation in Speaking English Through Active Learning Strategy. Research and Innovation in Language Learning, 1(2), 76. https://doi.org/10.33603/rill.v1i2.1075

Bailey, K., \& Nunan, D. (2004). Speaking. McGraw-Hill.

Brown, H. D. (2000). Teaching by Principles. Pearson ESL.

Brown, H. D., \& Abeywickrama, P. (2010). Language Assessment Principles and Classroom Practice. Pearson Education, Inc.

Bygate, M. (1987). Language Teaching: Speaking. Oxford University Press.

Cammeron, L. (2001). Teaching Languages to young Learners (p. 256). Cambridge University Press.

Christensen, L. B., Johnson, R. B., \& Turner, L. A. (2014). Design, and Analysis twelfth edition. Pearson.

Cooper, R., Fleischer, A., \& Cotton, F. A. (2012). Building connections: An interpretative phenomenological analysis of qualitative research students' learning experiences. Qualitative Report, 17(17), 1-16.

Dagmar, W. (2012). Benefits of Self-assessment in English classes at Elementary Schools Bachelor Thesis Prohlášení (Issue April). Masaryk University Brno Faculty.

Etikan, I. (2016). Comparison of Convenience Sampling and Purposive Sampling. American Journal of Theoretical and Applied Statistics, 5(1), 1. https://doi.org/10.11648/j.ajtas.20160501.11

Ferdiant, A. G. (2016). DEVELOPING THE ASSESSMENT INSTRUMENT OF SPEAKING. OKARA Journal of Languages and Literature, 1(1), 93-103.

Goh, C. C. M., \& Burns, A. (2012). Teaching Speaking. Cambridge University Press.

Groenewald, T. (2004). A Phenomenological Research Design Illustrated. International Journal of Qualitative Methods, 3(1), 42-55. https://doi.org/10.1177/160940690400300104

Harmer, J. (2007). How to teach english. Pearson ELT.

Himawan, A. N. (2015). THE USE OF POSTER CAROUSEL IN CLT METHOD (Issue October 2014). Universitas Ahmad Dahlan.

Hughes, A. (2002). Testing for Language Teacher. Cambridge University Press. 
Luoma, S. (2013). Assessing Speaking. Cambridge University Press. https://doi.org/10.1017/CBO9781107415324.004

Madani. (2019). AUTHENTIC ASSESSMENT OF SPEAKING SKILLS IN EFL CLASS (A Descriptive Qualitative Analysis on English Teacher"s Assessment Process at the Second Grade Students of Senior High School Pancasila Bengkulu). State University of Islamic Studies (IAIN) Bengkulu.

Nirmawati, L. A. (2013). Improving students' speaking skills through (Issue 09202241084). Yogyakarta State University.

Ounis, A. (2017). The Assessment of Speaking Skills at the Tertiary Level. International Journal of English Linguistics, 7(4), 95. https://doi.org/10.5539/ijel.v7n4p95

Pawlak, M. (2015). Issues in Teaching, Learning and Testing Speaking in a Second Language. In Issues in Teaching, Learning and Testing Speaking in a Second Language (Issue December 2015). https://doi.org/10.1007/978-3-642-38339-7

Rahmawati, Y., \& Ertin, E. (2014). Developing Assessment for Speaking. IJEE (Indonesian Journal of English Education), 1(2), 199-210. https://doi.org/10.15408/ijee.v1i2.1345

Rian Wulandari. (2014). Improving Student's Speaking Ability Through Communicative Language Game at SMPN 1 Prambanan Grade VIII A In The Academic Year Of 2013/2014. In English Education Department Faculty of Language and Arts Yogyakarta State University (Vol. 8, Issue 33). Yougyakarta State University.

Sarah Hillyard. (2013). Informal assessment tools in kindergarten. Argentinian Journal of Applied Linguistics, 1(1), 45-55.

Tampubolon, T. C. (2018). Improving Students' Motivation in Speaking through Collaborative Learning. International Journal of English Literature and Social Sciences, 3(2), 185-191. https://doi.org/10.22161/ijels.3.2.10

Thornbury, S. (2005). How to Teach Speaking. Longman.

Vodopija-Krstanović, I., \& Marinac, M. (2019). English as an international language and English language teaching: The theory vs. practice divide. Iranian Journal of Language Teaching Research, 7(2), 19-38.

Widiastuti, I. A. M. S., \& Saukah, A. (2017). Formative Assessment in Efl Classroom Practices. Bahasa Dan Seni: Jurnal Bahasa, Sastra, Seni Dan Pengajarannya, 45(1), 050-063. https://doi.org/10.17977/um015v45i12017p050

\section{Conflict of Interest}

No potential conflict of interest is reported.

\section{Author Biography}

Arifin Nur Himawan (corresponding author) and Dinar Purwati are English graduate students of Universitas Ahmad Dahlan. Both researchers are interested in developing English Language Teaching research. They can be reached at arifinhimawan92@gmail.com, and dynar.anisa13@gmail.com. 